\title{
Basis for a Predictive Model of Xanthomonas arboricola pv. pruni Growth and Infections in Host Plants
}

\author{
G. Morales ${ }^{1}$, I. Llorente ${ }^{1}$, E. Montesinos ${ }^{1}$ and C. Moragrega ${ }^{1}$ \\ Institute of Food and Agricultural Technology-XaRTA-CIDSAV, University of Girona. Girona, Spain
}

\begin{abstract}
Xanthomonas arboricola pv. pruni (Xap) is the causal agent of bacterial spot disease of stone fruits and almond. The bacterium is considered a quarantine pathogen in Europe and it has become a new and emerging threat for European crops. As the disease is strongly influenced by the weather, a forecasting model that predicts Xap infections based on climatic conditions could be implemented in stone fruit integrated pest management. The objective of this work was to constrain the basis for the development of a predictive model of Xap growth and infections, determining the effects of pathogen, host and climatic parameters on infection and disease development. A non-pathogenic specialization of Xap and cross-infection among host species was observed, although strains isolated from peach were the most virulent in peach leaves. Xap was able to infect unwounded leaves and it was observed that the presence of wounds on the leave surface did not favour Xap penetration in peach leaves. Otherwise, the water condition of plants played an important role in Xap infections and disease development in peach. The presence of water congestion and leaf wetness $48 \mathrm{~h}$ before inoculation favoured $\mathrm{Xap}$ infections and the duration of leaf wetness after inoculation was directly correlated to disease severity. Temperature and leaf age had a significant effect on Xap infections. Temperatures above $20^{\circ} \mathrm{C}$ favoured Xap infections, which were basically produced in young leaves; whereas severity was significantly lower at temperatures below $15^{\circ} \mathrm{C}$ and in mature leaves.
\end{abstract}

Keywords: bacterial spot of stone fruits, peach, temperature, virulence, wetness period.

\section{INTRODUCTION}

Xanthomonas arboricola pv. pruni (Xap) is the causal agent of bacterial spot disease of stone fruits and almond (EPPO/CABI, 1997; Palacio-Bielsa et al., 2010). The bacterium is considered a quarantine pathogen in Europe (Anonymous, 2000) and it has become a new and emerging threat for European crops. Control methods are limited to preventive copper sprays early in the growing season, quarantine measures to avoid introduction and spread, and a rapid detection and eradication of the outbreaks (Boudon et al., 2005; Janse, 2012; Palacio-Bielsa et al., 2012).

The disease is strongly influenced by climatic conditions (Battilani et al., 1999; Bugiani et al., 2008), therefore Xap growth and infections could be predicted as function of different environmental parameters. Forecasting, decision support systems and risk mapping could be implemented in stone fruits integrated pest management. The objective of this work was to set up the basis for developing a prediction model of Xap growth and infection in host plants performed under greenhouse conditions that combine the effects of temperature and wetness duration. For this purpose, the effects of pathogen (virulence, ways of penetration in host), host (leaf age, water condition) and climatic parameters (wetness and temperature) on infection and disease development were determined.

\section{MATERIALS AND METHODS}

\footnotetext{
a E.mail: gerard.morales@udg.edu
} 


\section{Virulence of Strains}

Seven strains of Xap isolated from different origins (host plant species and country) (Table 1) were evaluated. Bacterial suspensions were resuspended in sterile distilled water from LB agar cultures grown at $27^{\circ} \mathrm{C}$ for $24-48 \mathrm{~h}$ and adjusted to $0,5 \mathrm{OD}$ at $600 \mathrm{~nm}$, corresponding to approximately $10^{9} \mathrm{CFU} \mathrm{ml}^{-1}$. Peach leaves (Prunus persica 'Big Top'), recovered from one-year-old potted plants grown in the greenhouse, were surface disinfected by immersion for 30 s in a $5 \%$ solution of commercial sodium hypochlorite, rinsed three times with sterile distilled water and inoculated with each strain. For inoculation, a wound was done on the midvein by a single transverse incision using a scalpel and a $30 \mu \mathrm{L}$ drop of $10^{9} \mathrm{CFU} \mathrm{ml}^{-1}$ Xap suspension was placed onto the wound. Leaves inoculated with distilled water were used as controls. Three replicates of three leaves were inoculated with each strain, placed inside a plastic box that was covered with a plastic bag to maintain high relative humidity and incubated for 14 days at $25^{\circ} \mathrm{C}$ and 16 -h light photoperiod in a controlled-environment chamber. Disease severity was assessed at the end of incubation time according to a 0-3 index scale (Moragrega et al., 1998; Ruz et al., 2008). The experiment was repeated twice. Additionally, the virulence of the strains originally isolated from peach was assessed on unwounded peach leaves. Five leaves were dipped into $10^{9} \mathrm{CFU} \mathrm{ml}{ }^{-1}$ suspensions of strains CFBP 5530, CFBP 5563 and CFBP 5725 respectively, placed inside a plastic box that was covered with a plastic bag and incubated at optimal conditions for disease development for 14 days, as described previously. Five leaves inoculated with sterile distilled water were used as controls. Disease severity was assessed at the end of incubation time following a $0-5$ scale index corresponding to an area affected by 1, 3, 6, 12 and 24\% or more, respectively (Battilani et al., 1999; Garcin et al., 2011).

\section{Pathogen Penetration in Host}

In order to determine whether Xap is able to penetrate host tissues through natural openings or wounds are required, detached 'Big Top' peach leaves were inoculated by pulverization with a $10^{9} \mathrm{CFU} \mathrm{ml-1}$ Xap CFBP 5563 suspension until runoff using an airbrush. Diatomaceous earth $\left(0.2 \mathrm{mg} \mathrm{ml}^{-1}\right)$ was added to bacterial suspensions as an abrasive agent to produce wounds and three spraying pressures $(50,100$ and $200 \mathrm{kPa}$ ) were tested. Treatments consisted of inoculation of bacterial suspensions with or without the abrasive agent (wound and unwounded leaves) and three spraying pressures. Three replicates of three leaves per replicate were used for each treatment. Leaves inoculated with distilled water at $200 \mathrm{kPa}$ with and without the abrasive agent were used as controls. Inoculated leaves were placed in humid chambers and incubated for 16 days at $25^{\circ} \mathrm{C}$ and 16 -h light photoperiod in a growth cabinet. Disease severity was assessed 13 and 16 days after pathogen inoculation following a 0-5 scale index, as described previously.

\section{Water Condition of Peach Plants}

The effect of water congestion and leaf wetness of peach plants before and after pathogen inoculation on Xap infections was assessed. Two sets of 'Big Top' potted peach plants were separated in the greenhouse before inoculation for different water treatments. One set of plants was maintained under sprinklers that were activated when leaf surface became dry using wetness sensors, and were covered with a plastic canvas that ensure 100 $\%$ relative humidity (RH) for $48 \mathrm{~h}$. The second set of plants was subjected to a $60-80 \% \mathrm{RH}$ without wetness under greenhouse conditions. Plants were inoculated with a $10^{9} \mathrm{CFU} \mathrm{ml}-1$ Xap CFBP 5563 suspension by leaf pulverisation at $100 \mathrm{kPa}$ until runoff, and placed into plastic bags to ensure leaf wetness persistence for 24 or $48 \mathrm{~h}$. After 24 or $48 \mathrm{~h}$ plants were transferred to a quarantine greenhouse where plastic bags were removed and plants were incubated at $20^{\circ} \mathrm{C}, 60-80 \%$ humidity and 12-h light photoperiod for 21 days. Three combinations of water treatments were assessed: $48 \mathrm{~h}$ wetness before and $24 \mathrm{~h}$ wetness after inoculation; $48 \mathrm{~h}$ wetness before and $48 \mathrm{~h}$ wetness after inoculation; no wetness before 
and $48 \mathrm{~h}$ wetness after inoculation. Plants inoculated with distilled water and subjected to $48 \mathrm{~h}$ wetness before and $48 \mathrm{~h}$ wetness after inoculation were used as controls. Three plants were used for each water condition. Disease severity in the seven youngest completely formed leaves at the moment of inoculation in a plant was assessed 14 and 21 days after pathogen inoculation following a 0-5 scale index, as described previously.

\section{Effect of Temperature on Xap Infection in Peach}

The effect of temperature $\left(5,10,15,20,30\right.$ and $\left.35^{\circ} \mathrm{C}\right)$ on bacterial infection was determined. 'Big Top' potted peach plants were inoculated with a $10^{9} \mathrm{CFU} \mathrm{ml}^{-1} \mathrm{Xap}$ CFBP 5563 suspension ( $0.2 \mathrm{mg} \mathrm{ml}^{-1}$ diatomaceous earth) by pulverisation of leaves at $100 \mathrm{kPa}$ until runoff. Before inoculation, plants were maintained in the greenhouse for 48 hours under sprinklers and a plastic canvas to assure leaf wetness and 100\% RH (as described previously). After inoculation, plants were introduced into transparent plastic bags to maintain leaf wetness and incubated at different temperatures for 24 hours in a controlledenvironment chamber. Plants were then transferred to a quarantine greenhouse where the plastic bags were removed and plants were incubated at $20^{\circ} \mathrm{C}, 60-80 \%$ humidity and 12 -h light photoperiod for 21 days. Five plants were used per condition. Plants inoculated with distilled water $\left(0.2 \mathrm{mg} \mathrm{ml}^{-1}\right.$ diatomaceous earth) were used as controls. Disease severity was assessed in the five youngest leaves in a plant 14 and 21 days after pathogen inoculation, following a 0-5 scale index, as described previously. The experiment was performed two times.

\section{Effect of Peach Leaf Age}

Plants from previous assay on the effects of temperature were used in this experiment. Disease severity in plants exposed to temperatures of 20,25 , and $30^{\circ} \mathrm{C}$ was recovered individually for each leave in a plant. The position of each leaf in the twig was noted. Two leaf ages were established: young (leaves not fully expanded at the moment of inoculation) and old (mature leaves formed one-two weeks before inoculation). Five plants were used per temperature and leaf age. The experiment was performed two times.

\section{Data Analysis}

Disease severity (S) was calculated for each replicate or plant, depending on the experiment, according to the following formula:

$$
\mathrm{S}=\sum_{n=1}^{N} \frac{I_{n}}{N \times I_{\max }} \times 100
$$

where $I_{n}$ is the severity index for an inoculation/leaf, $N$ is the number of inoculations/leaves in a replicate/plant, and $I_{\max }$ is the maximum index value in the scale.

Treatment effects on disease severity were analysed by means of repeated measures analysis of variance (ANOVA) for parametric data or the Kruskal-Wallis test for nonparametric data using IBM SPSS Statistics Version 19. Differences among treatments were analysed using Tukey's LSD mean comparison test or pairwise comparisons for nonparametric analysis.

\section{RESULTS \\ Virulence of Strains}

The seven strains isolated from different hosts and countries were pathogenic on peach, since disease symptoms were observed for all strains on peach leaves at the end of incubation time. Significant differences in disease severity in peach leaves were observed among strains of Xap ( $p=0.045$ ) (Figure 1). Strains isolated from peach (CFBP 5530, CFBP 5563 and CFBP 5725) were highly virulent with disease severity from 40 to $60 \%$ for wounded and unwounded peach leaves. Strains IVIA 33 and IVIA 3162-1 isolated from 
almond and strain CFBP 3903 isolated from plum were moderately virulent (disease severity from 24 to 42.6\%). The type strain CFBP 3894 isolated from Japanese plum was the less virulent on peach, with a mean disease severity of $18.5 \%$.

\section{Pathogen Penetration in Host}

The disease severity in detached peach leaves inoculated with Xap CFBP 5563 increased through the incubation time, from $20-40 \% 13$ days after inoculation to $80-90 \%$ at 16 days. The addition of diatomaceous earth as an abrasive agent in bacterial suspensions did not increase the disease severity in plant leaves. No differences were observed among treatments with the addition of an abrasive agent in disease severity values for each incubation time ( $p=0.422$ and 0.951 for 13 and 16 days, respectively). Moreover, spraying pressures $(50,100$ and $200 \mathrm{kPa})$ used for inoculation of pathogen did not have a significant effect on disease severity $(p>0.7)$.

\section{Water Condition of Peach Plants}

First disease symptoms on leaves were observed 10 days after inoculation. Disease severity increased from 14 to 21 days after pathogen inoculation. Significant differences in final disease severity were observed depending on water condition of plants $(p=0.002)$. Plants submitted to irrigation and continuous leaf wetness $48 \mathrm{~h}$ before inoculation and incubated with continuous leaf wetness for additional $48 \mathrm{~h}$ after inoculation displayed significantly higher disease severity (74.4\%) at the end of incubation time. Plants maintained under irrigation and continuous leaf wetness for $48 \mathrm{~h}$ prior to inoculation but with a reduction to $24 \mathrm{~h}$ of leaf wetness after inoculation were less infected and final disease severity was reduced (41\%). Similar results were obtained in plants not exposed to water congestion before pathogen inoculation and $48 \mathrm{~h}$ of leaf wetness post-inoculation (35.6\%).

\section{Effect of Temperature on Xap Infection in Peach}

Differences among experiments were observed in final disease severity values in most temperatures tested. These differences could be attributed to the differences in plant material used. Experiment 1 was performed in spring, after bud break and experiment 2 was performed in autumn, six months later. Although a significant effect of temperature on disease severity was observed in both experiment replicates, the relationship between temperature and final disease severity was more evident in plants inoculated after bud break (experiment 1 ) than in autumn (experiment 2). In experiment 1, incubation at low temperatures $\left(5\right.$ to $\left.15^{\circ} \mathrm{C}\right)$ resulted in low disease severity, whereas incubation at higher temperatures (from 20 to $35^{\circ} \mathrm{C}$ ) produced higher disease severity. In experiment 2, disease severity values in plants incubated at $10,15,20$ and $25^{\circ} \mathrm{C}$ were lower than in experiment 1. However, in both experiments the maximum disease severity was observed at $30^{\circ} \mathrm{C}$ with values between 40 and $45 \%$ (Figure 2).

\section{Effect of Peach Leaf Age}

A significant effect of leaf age was observed on disease severity caused by Xap on peach plants at all temperatures tested. Young leaves (corresponding to the newly formed leaves) were significantly more susceptible to Xap infections (40-50\%) than mature leaves with lower disease severity values (15-26.8\%). When disease severity was assessed regarding the position of the leaf in the twig, a progressive decrease of severity was observed from the apical to the basal placement. Therefore, the younger the leaf the more susceptible was to Xap infections (Figure 3).

\section{DISCUSSION}

All Xap strains were able to infect peach leaves, although some of them were originally isolated from other host species. Nevertheless, Xap strains isolated from peach were the most virulent on peach leaves. Despite the fact that the virulence of strains varied, these 
results confirmed the existence of non-pathogenic specialization and the possibility of crossinfection among hosts (Scortichini et al., 1996).

It is known that Xap infection may be produced via natural opening such as stomata, hydathodes or glands (EPPO/CABI, 1997). Nevertheless, under field conditions leaves may have wounds on surface caused by friction in windy days, hail, insect bites, etc., which could also be used by Xap to penetrate the host in addition to the natural openings. These wounds could be simulated at the laboratory adding an abrasive agent in the bacterial suspension, such as diatomaceous earth. It was expected that artificially wounded leaves would be more sensitive to Xap infections in agreement to the reported mechanical transmission of Xap during pruning in plum nurseries (Goodman and Hattingh, 1986) or the results obtained in the evaluation of inoculation techniques (Socquet-Juglard et al., 2012). However, there were no differences in disease severity produced by Xap infections in artificially injured peach leaves compared to unwounded leaves; in both cases the disease severity was similar. The reason for the similar severity values in both treatments (wounded and unwounded leaves) could be that all parameters were optimal for Xap infections succeed. Plants were grown at the greenhouse and they were well irrigated, thus stomata were hydrated and opened to transpire. Xap might have used those natural openings to produce infections and artificial wounds did not increase the disease severity. In addition, young leaves were selected to be inoculated with a high concentration of Xap applied with pressure by pulverization. Otherwise, under field conditions there are not such favourable conditions for infections. Firstly, stomata are not always open for the penetration and infection of Xap, because the stomata opening plays an important role in the hydric balance of the plant and it is conditioned by the water potential in soil and atmosphere. Secondly, the cuticle of plants under field conditions may be thicker than the cuticle of plants grown in the greenhouse, forming a physical barrier that resists the penetration of pathogens.

Similarly, the pressure at which Xap suspensions were inoculated on the surface of leaves did not had a significant effect on bacterial infection. Nevertheless, pulverization of pathogen at a pressure of $50 \mathrm{kPa}$ resulted in large drops of bacterial suspension, not optimal for uniform distribution of pathogen on leaves. On the other hand, pulverization of pathogen at a pressure of $200 \mathrm{kPa}$ produced a high flow of pathogen suspension and a low uniformity of pathogen distribution. The optimal pulverization pressure for uniform distribution of pathogen suspension on leaf surface was $100 \mathrm{kPa}$, which was selected for spraying the bacterial suspension in further assays.Previous studies concluded that water congestion before inoculation followed by a period of leaf wetness after inoculation was necessary for symptom development of Xap infections (Zehr and Shepard, 1996). Our study demonstrated that $48 \mathrm{~h}$ of leaf wetness combined with appropriate irrigation before inoculation caused water congestion in leaves that lead to a rapid entry of pathogen into the leaves through the congested stomata. Additionally, a wetness period of $48 \mathrm{~h}$ after inoculation was shown to increase the disease severity compared to $24 \mathrm{~h}$ of wetness. However, some infections were observed when neither water congestion nor wetness was present before inoculation, although the severity was significantly lower. To conclude, the presence of water congestion and leaf wetness before and after inoculation may favour Xap infections in peach.

The temperature is an important factor for infection and development of plant diseases. Xap infections were reduced in plants submitted to low temperatures during the $24 \mathrm{~h}$ after the inoculation and increased as the temperature rise. The maximal disease severity was observed at $30^{\circ} \mathrm{C}$, in agreement with the optimal temperature for Xap growth in vitro (Young et al., 1977). At $35^{\circ} \mathrm{C}$, the mean value of disease severity decreased, but it had a large variability. The reason of this variability could be related to the fact that the temperature of $35^{\circ} \mathrm{C}$ is the upper limit for Xap growth, previously determined in vitro (data not shown). 
Our results demonstrated an ontogenic resistance of peach leaves to Xap. Leaves completely formed at the moment of inoculation and monitored during the experiments were less infected than newly formed leaves. Therefore, under field conditions disease symptoms would probably be more important in growing shots than in old leaves.

A forecasting model for Xap infections in host plants is now in progress in order to improve the efficiency of management actions on stone fruit crops against the bacterial spot disease. The results obtained in the present study are taken into account to develop this forecasting model of Xap infections in host plants.

\section{CONCLUSIONS}

The following conclusions can be drawn from the study:

- There was a non-pathogenic specialization of Xap; consequently, cross-infection among host species could be produced.

- Wounds on leave surface were no necessary for Xap infections, which may be produced via natural opening such as stomata, hydathodes or glands.

- The presence of water congestion and leaf wetness $48 \mathrm{~h}$ before inoculation favoured Xap infections.

- The duration of leaf wetness after inoculation was directly correlated to disease severity.

- Temperatures above $20^{\circ} \mathrm{C}$ favoured Xap infections.

- There is an ontogenic resistance of peach leaves to Xap infections. Severity was higher in young leaves than in mature ones.

\section{ACKNOWLEDGEMENTS}

Supported by research grants BR 2013/31 from University of Girona and FPU13/04123 from Spain MECD, and the projects AGL2013-41405-R from Spain MINECO and the European Union Seventh Framework (FP7 / 2007-2013) under the agreement $\mathrm{n}^{\circ} 613678$ (DROPSA).

\section{Literature cited}

Anonymous (2000). Council Directive 2000/29/EC of 8 May 2000 on protective measures against the introduction into the Community of organisms harmful to plants or plant products and against their spread within the Community. Off. J. Eur. Communities L 169, 1146.

Battilani, P., Rossi, V., and Saccardi, A. (1999). Development of Xanthomonas arboricola pv. pruni epidemics on peaches. J. Plant Pathol. 81, 161-171.

Boudon, S., Manceau, C., and Nottéghem, J.-L. (2005). Structure and Origin of Xanthomonas arboricola pv. pruni Populations Causing Bacterial Spot of Stone Fruit Trees in Western Europe. Phytopathology 95, 1081-1088.

Bugiani, R., Giosuè, S., Gianni, C., and Rossi, V. (2008). Prediction of Xanthomonas arboricola pv. pruni infection on peaches. In Proceedings of the 7th International Conference on Integrated Fruit Production, 27-30 October 2008, Avignon, France, pp. 482-486.

EPPO/CABI (1997). Data sheets on quarantine pests Xanthomonas arboricola pv. pruni.

Garcin, A., Vibert, J., and Leclerc, A. (2011). Xanthomonas sur pêcher. étude des conditions d'infection. Développement de l'outil (1re partie). Infos CTIFL 268, 26-39.

Goodman, C.A., and Hattingh, M.J. (1986). Transmission of Xanthomonas campestris pv. pruni in plum and apricot nursery trees by budding. HortScience 21, 995-996.

Janse, J.D. (2012). Bacterial diseases that may or do emerge, with (possible) economic 
damage for europe and the mediterranean basin: Notes on epidemiology, risks, prevention and management on first occurrence. J. Plant Pathol. 94, S4.5-S4.29.

Moragrega, C., Manceau, C., and Montesinos, E. (1998). Evaluation of drench treatments with phosphonate derivatives against Pseudomonas syringae pv. syringae on pear under controlled environment conditions. Eur. J. Plant Pathol. 104, 171-180.

Palacio-Bielsa, A., Roselló, M., Cambra, M.A., and López, M.M. (2010). First report on almond in Europe of bacterial spot disease of stone fruits caused by Xanthomonas arboricola pv. pruni. Plant Dis. 94, 786.

Palacio-Bielsa, A., Pothier, J., Roselló, M., Duffy, B., and López, M.M. (2012). Detection and identification methods and new tests as developed and used in the framework of cost 873 for bacteria pathogenic to stone fruits and nuts. J. Plant Pathol. 94, S1.135-S1.146.

Ruz, L., Moragrega, C., and Montesinos, E. (2008). Evaluation of four whole-plant inoculation methods to analyze the pathogenicity of Erwinia amylovora under quarantine conditions. Int. Microbiol. 11, 111-119.

Scortichini, M., Janse, J.D., Rossi, M.P., and Derks, J.H.J. (1996). Characterization of Xanthomonas campestris pv. pruni strains from different hosts by pathogenicity tests and analysis of whole-cell fatty acids and whole-cell proteins. J. Phytopathol. 144, 69-74.

Socquet-Juglard, D., Patocchi, A., Pothier, J.F., Christen, D., and Duffy, B. (2012). Evaluation of Xanthomonas arboricola pv. pruni inoculation techniques to screen for bacterial spot resistance in peach and apricot. J. Plant Pathol. 94, S1.91-S1.96.

Young, J., Luketina, R., and Marshall, A. (1977). The effects on temperature on growth in vitro of Pseudomonas syringae and Xanthomonas pruni. J. Appl. Bacteriol. 42, 345-354.

Zehr, E.I., and Shepard, D.P. (1996). Bacterial Spot of Peach as Influenced by Water Congestion, Leaf Wetness Duration, and Temperature. Plant Dis. 80, 339-341.

\section{Tables}

Table 1. List of Xanthomonas arboricola pv. pruni strains used in this study.

\begin{tabular}{ccc}
\hline Strain $^{\text {a }}$ & Host & Origin country \\
\hline CFBP 3894b & Japanese plum & New Zealand \\
CFBP 3903 & Plum & Italy \\
CFBP 5530 & Peach & Italy \\
CFBP 5563 & Peach & France \\
CFBP 5725 & Peach & EUA \\
IVIA 33 & Almond & Spain \\
IVIA 3162-1 & Almond & Spain \\
\hline a CFBP, Collection Française de Bactéries associées aux Plantes (Angers, France); \\
IVIA, Instituto Valenciano de Investigaciones Agrarias (Moncada-Valencia, Spain) \\
b Pathotype strain
\end{tabular}




\section{Figures}

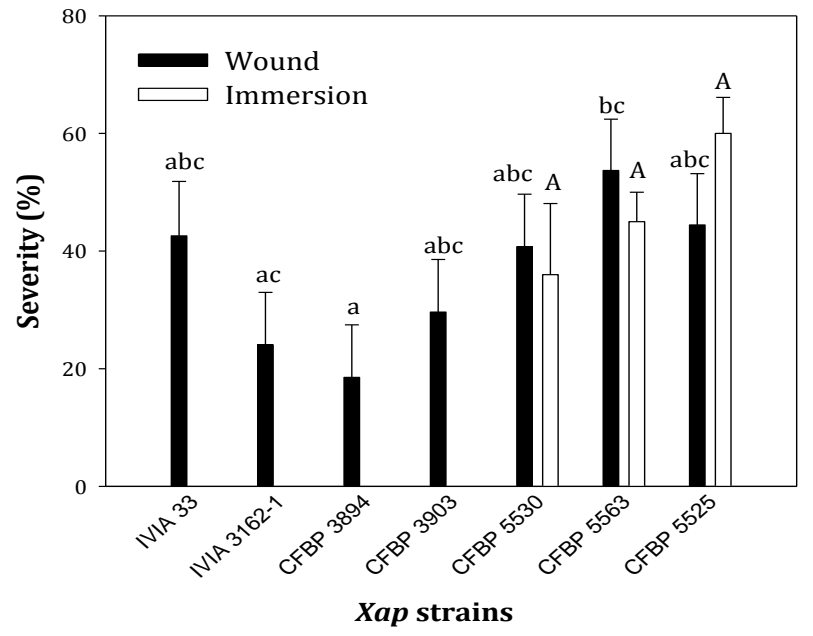

Figure 1. Virulence of Xanthomonas arboricola pv. pruni strains inoculated on peach cv. Big Top detached leaves, by deposition on a wound or by unwounded leaf immersion. Disease severity was recorded 14 days after inoculation. Values are the mean of five leaves. Error bars are the standard error. Different letters on a bar indicate significant $(p=0.05)$ differences in virulence among strains inoculated on wounded leaves (lower case) or by leaf immersion (upper case).

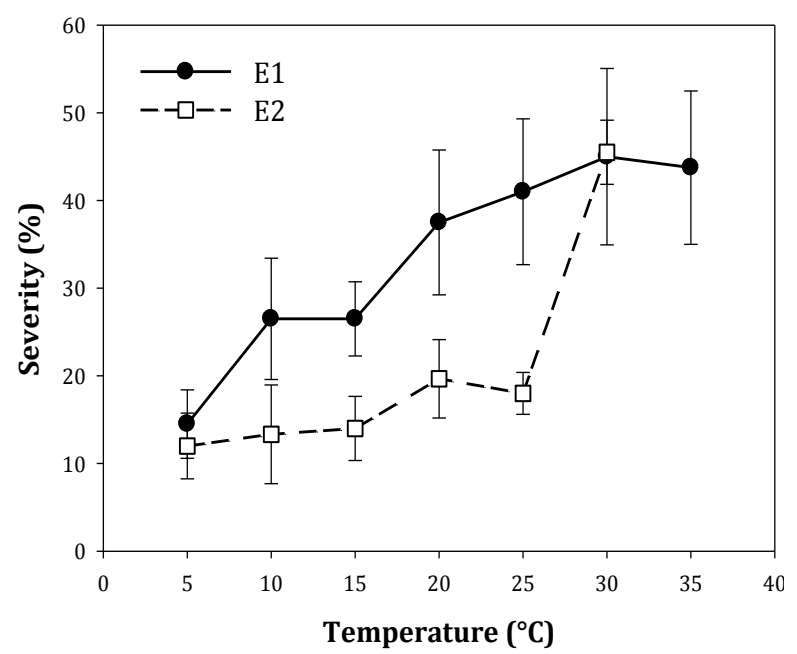

Figure 2. Temperature effect on Xanthomonas arboricola pv. pruni infection in peach plants cv. Big Top. Plants were exposed to different temperatures for $24 \mathrm{~h}$ after inoculation with Xap CFBP 5563 suspensions $\left(10^{9} \mathrm{CFU} \mathrm{ml}{ }^{-1}\right)$, and then incubated at optimal conditions for disease development for 21 days. Values are the mean disease severity of five plants at the end of incubation period. Two independent experiments are presented (E1 and E2). Error bars are the standard error of mean. 

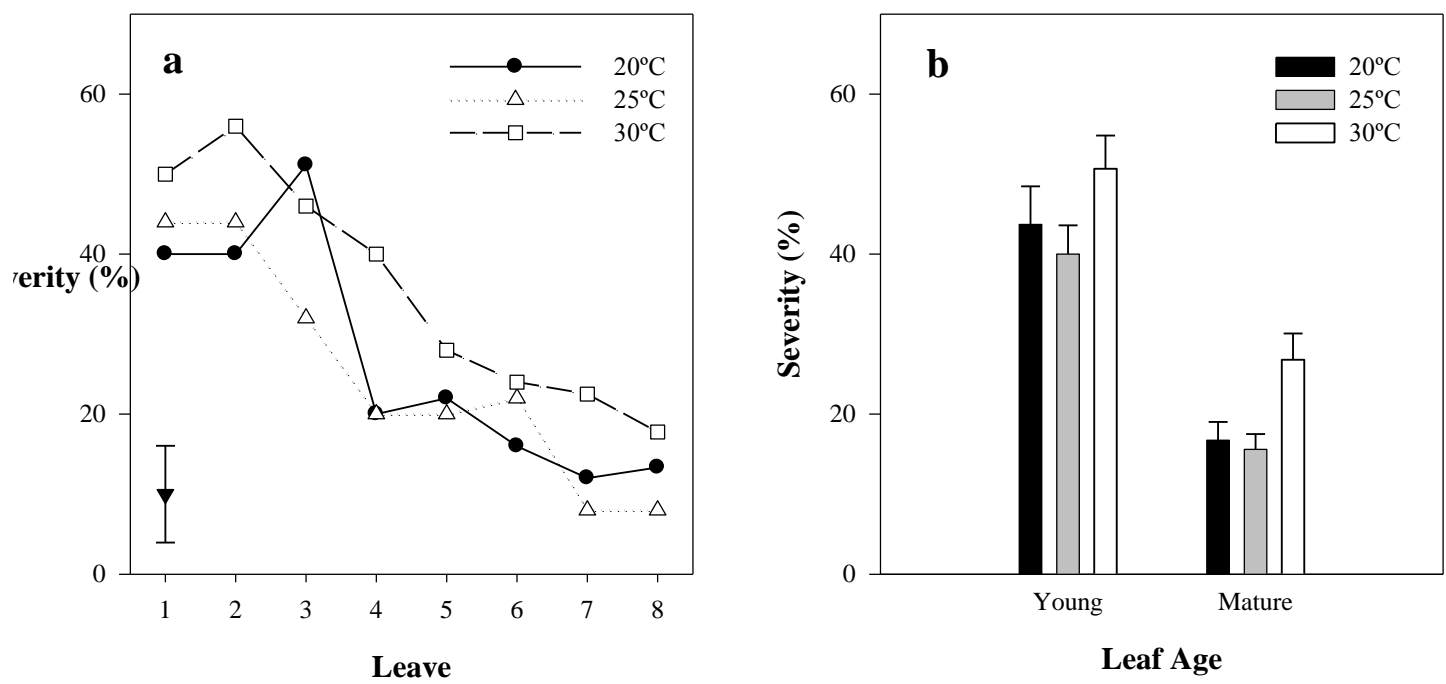

Figure 3. Leaf age effect on disease severity caused by Xanthomonas arboricola pv. pruni in peach plants cv. Big Top. Disease severity was assessed 14 days after inoculation with Xap CFBP 5563 suspensions $\left(10^{9} \mathrm{CFU} \mathrm{ml}^{-1}\right)$. Plants were incubated for $24 \mathrm{~h}$ after inoculation at different temperatures and then transferred to optimal conditions for disease development. Severity values are the mean of ten plants. Error bar (lower left corner) represents the mean standard error. (a) Leaf position is indicated for a total of eight leaves in a plant from the apical leaf (1) to the basal leaf (8). (b) Leaf age was considered as young for leaves not fully expanded at the moment of inoculation and mature for those completely formed before inoculation. Different letters indicate differences among treatments according to a least significant difference test $(p=0.05)$. 